\title{
Histone modifications as regulators of life and death in Saccharomyces cerevisiae
}

\author{
Birthe Fahrenkrog* \\ Institute of Molecular Biology and Medicine, Université Libre de Bruxelles, Rue Profs. Jeener et Brachet 12; 6041 Charleroi, Belgium. \\ * Corresponding Author: Birthe Fahrenkrog, E-mail: bfahrenk@ulb.ac.be
}

\begin{abstract}
Apoptosis or programmed cell death is an integrated, genetically controlled suicide program that not only regulates tissue homeostasis of multicellular organisms, but also the fate of damaged and aged cells of lower eukaryotes, such as the yeast Saccharomyces cerevisiae. Recent years have revealed key apoptosis regulatory proteins in yeast that play similar roles in mammalian cells. Apoptosis is a process largely defined by characteristic structural rearrangements in the dying cell that include chromatin condensation and DNA fragmentation. The mechanism by which chromosomes restructure during apoptosis is still poorly understood, but it is becoming increasingly clear that altered epigenetic histone modifications are fundamental parameters that influence the chromatin state and the nuclear rearrangements within apoptotic cells. The present review will highlight recent work on the epigenetic regulation of programmed cell death in budding yeast.
\end{abstract}

\author{
doi: 10.15698/mic2016.01.472 \\ Received originally: 11.09.2015; \\ in revised form: 11.11.2015, \\ Accepted 27.11.2015 \\ Published 31.12.2015. \\ Keywords: apoptosis, autophagy, \\ epigenetics, histone modification, \\ Saccharomyces cerevisiae, yeast. \\ Abbreviations: \\ CLS - chronological lifespan, \\ $D S B S$ - DNA double strand breaks, \\ HAT - histone acetyltransferase, \\ HDAC - histone deacetylase, \\ $R L S$ - replicative lifespan, \\ ROS - reactive oxygen species.
}

\section{INTRODUCTION}

Apoptosis or "programmed cell death" is a self-destructing process important for the development and homeostasis of multicellular organisms and its deregulation contributes to the pathogenesis of multiple diseases including autoimmune, neoplastic and neurodegenerative disorders [1]. Apoptosis is characterized by biochemical and morphological rearrangements throughout the cell [2] with chromatin condensation conjoint by DNA fragmentation being one of the most important nuclear alterations [3]. The mechanism by which chromosomes reorganize during apoptosis is still poorly understood, but recent years have shown that epigenetic changes of the chromatin state are fundamental parameters of the nuclear rearrangements experienced by apoptotic cells.

Chromatin is a composite of packaged DNA and associated proteins, in particular histones [4]. The basic subunit of chromatin is the nucleosome containing 147 base pairs of DNA, which are wrapped around a histone octamer containing two copies each of the core histones H2A, H2B, H3 and $\mathrm{H} 4$. Nucleosomes are then packaged into higher order structures in a yet controversially discussed manner [5], in which individual nucleosomes are separated from each other by the linker histone $\mathrm{H} 1$ and its isoforms. The tails of the core histones pass through channels within the DNA molecule away from it and are subjected to a wide variety of post-translational modifications. These posttranslational modifications include lysine acetylation, bu- tyrylation, propionylation, ubiquitination and sumoylation, lysine and arginine methylation, arginine citrullination, serine, threonine and tyrosine phosphorylation, proline isomerization as well as ADP ribosylation [6-10]. In the context of apoptosis in particular phosphorylation and acetylation of histones have long been suggested to affect chromatin function and structure during cell death [11].

The budding yeast Saccharomyces cerevisiae has matured as attractive model system for apoptotic research to study the evolutionary conserved aspects of programmed cell death. Apoptosis in S. cerevisiae can be activated by various agents including hydrogen peroxide $\left(\mathrm{H}_{2} \mathrm{O}_{2}\right)$, acetic acid and pheromone or by physiological triggers, such as DNA replication stress, defects in DNA damage repair, chronological or replicative aging and failed mating [12-16]. The chronological lifespan (CLS) is defined as the time yeast cells remain alive in a post-mitotic, quiescence-like state [17-19] and genetically, amongst others, strongly influenced by key apoptotic regulators, such as Aif1, Bir1, Nma111, Nuc1, Ybh3 and Yca1 [20-28], all of which have homologs in mammals. Replicative aging, the second type of aging studied in yeast, is defined by the number of cell divisions an individual mother cell can undergo before entering senescence (replicative lifespan, RLS) and is equally controlled by some of these genetic factors as well as by environmental conditions $[17,19]$. Chronological and replicative aging both lead to an accumulation of reactive oxy- 
gen species (ROS) that ultimately results in programmed death of the budding yeast cells $[24,29]$.

As in higher eukaryotes, it is becoming more and more evident that the programmed death of $S$. cerevisiae is largely influenced by epigenetic modifications, in particular phosphorylation of $\mathrm{H} 2 \mathrm{~B}$ and $\mathrm{H} 3$, acetylation of $\mathrm{H} 3$ and $\mathrm{H} 4$, deubiquitination of $\mathrm{H} 2 \mathrm{~B}$, as well as methylation of $\mathrm{H} 3$ [3035]. This review will highlight current knowledge on the posttranslational histone modifications that decide on yeast life and death.

\section{EPIGENETIC REGULATION OF YEAST LIFE AND DEATH Histone phosphorylation}

In metazoans, the first histone modification that had been linked to apoptosis was phosphorylation of the histone variant H2A.X at serine 139 (S139), known as $\mathrm{\gamma}-\mathrm{H} 2 \mathrm{AX}$, that occurs during the formation of DNA double strand breaks (DSBs) under various conditions, including apoptosis [36]. Furthermore, phosphorylation of histone H2B at S14 had been associated with chromatin condensation and DNA fragmentation [37-39]. H2B phosphorylation is reciprocal and deacetylation of $\mathrm{H} 2 \mathrm{~B}$ at lysine 15 (K15) is necessary to allow H2BS14 phosphorylation [40].

This unidirectional crosstalk between two histone modifications was originally revealed in yeast: phosphorylation of $\mathrm{S} 10$ of $\mathrm{H} 2 \mathrm{~B}$ (H2BS10ph; Fig. 1) is essential for the induction of an apoptotic-like cell death in $\mathrm{H}_{2} \mathrm{O}_{2}$-treated cells [30]. H2BS10A point mutants exhibit increased cell survival accompanied by a loss of DNA fragmentation and chromatin condensation, whereas H2BS10E point mutants display the typical phenotypic markers of apoptosis, including chromatin compaction and DNA fragmentation. Triggering apoptosis by $\mathrm{H}_{2} \mathrm{O}_{2}$, acetic acid or the $\alpha$-factor leads to phosphorylation of $\mathrm{H} 2 \mathrm{BS} 10$ and $\mathrm{H} 2 \mathrm{BS} 10$ ph is preceded by $\mathrm{H} 2 \mathrm{~A}$ phosphorylation and mediated by the Sterile 20 kinase, Ste20 (Table 1) [30]. It is dependent on the yeast metacaspase Yca1 and the preceding deacetylation of lysine 11 [31].

$\mathrm{H} 2 \mathrm{~B}$ lysine 11 is acetylated (H2BK11ac) in logarithmically growing yeast [41] and deacetylated upon $\mathrm{H}_{2} \mathrm{O}_{2}$ treatment before H2BS10ph occurs. H2BK11ac was found to be present through 60 min of $\mathrm{H}_{2} \mathrm{O}_{2}$ treatment and the disappearance of $\mathrm{K} 11 \mathrm{ac}$ after 90 min post $\mathrm{H}_{2} \mathrm{O}_{2}$-induction coincided with the onset of S10ph in $\mathrm{H} 2 \mathrm{~B}$ [31]. The crosstalk between H2BS10ph and H2BK11ac is unidirectional and confirmed by H2BK11 mutants: lysine-to-glutamine H2B $\mathrm{K} 11 \mathrm{Q}$ mutants, that are acetyl-mimic, are resistant to cell death elicited by $\mathrm{H}_{2} \mathrm{O}_{2}$, while lysine-to-arginine $\mathrm{H} 2 \mathrm{~B}$ K11R mutants that imitate deacetylation promote cell death. Deacetylation of $\mathrm{K} 11$ is mediated by the histone deacetylase (HDAC) Hos3 (Table 1)[31].

Interestingly, in human cells it has been shown that H2BS14ph, which is mediated by caspase-activated kinase Mst1, is read by RCC1 [42]. RCC1 is chromatin-bound and the guanine nucleotide exchange factor for the RanGTPase, which acts as a molecular switch to regulate directionality

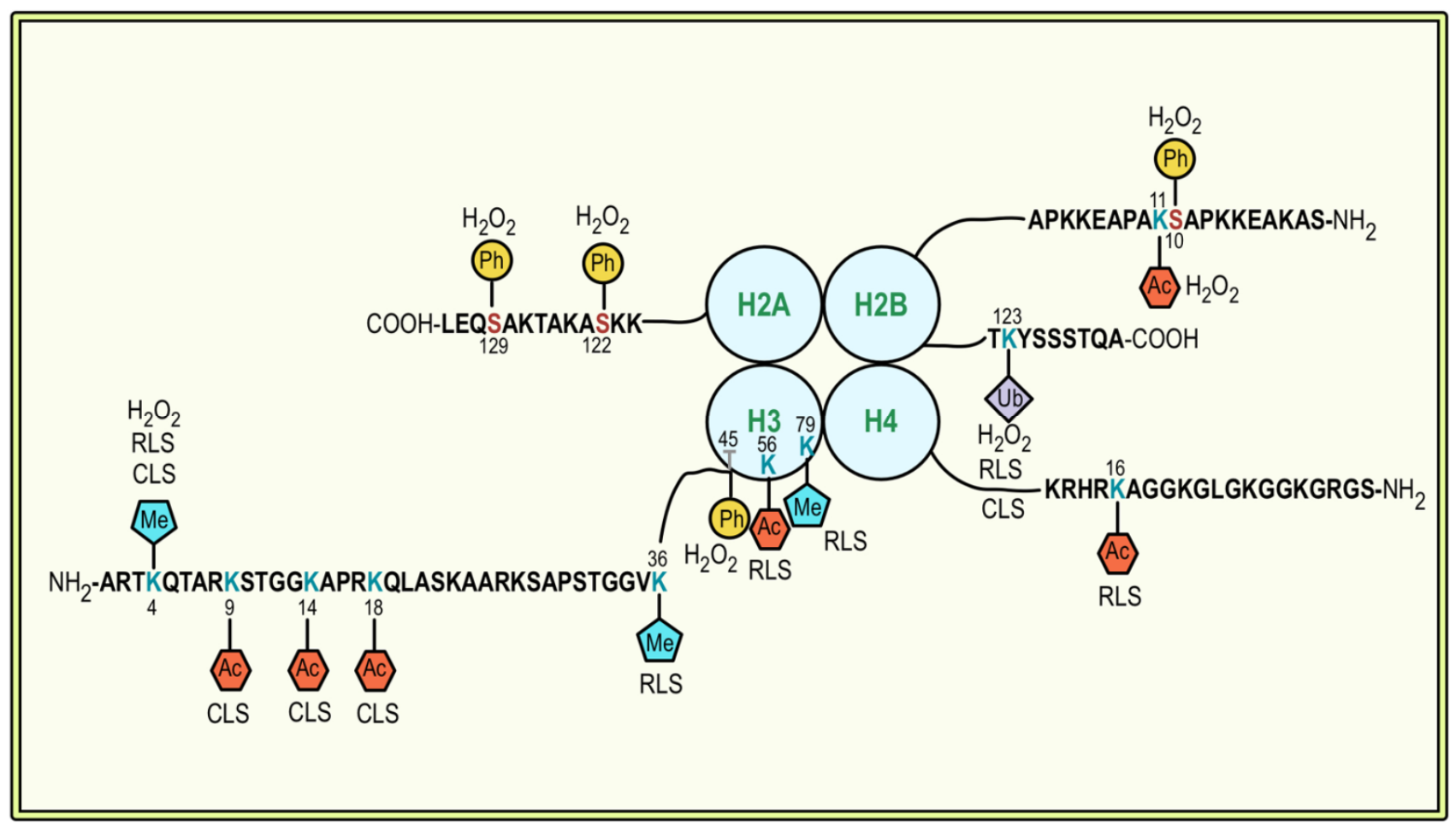

FIGURE 1: Specific histone modifications that have been shown to be associated with apoptotic cell death and lifespan regulation in $S$. cerevisiae. Modified lysine residues are highlighted in cyan, modified serine residues in red, and modified tyrosine residues in grey. Ac, acetylation; Me, methylation; Ph, phosphorylation; Ub, ubiquitination. 
of nucleocytoplasmic transport as well as distinct steps of mitosis, such as spindle and nuclear envelope assembly [43-45]. H2BS14ph immobilizes RCC1 on chromatin, which causes a reduction of nuclear RanGTP levels and the inactivation of the nucleocytoplasmic transport machinery [42], which in turn contributes to the inactivation of survival pathways, such as NF-KB signaling [11]. Whether H2BS10ph in yeast has a similar effect on the nucleocytoplasmic transport machinery and survival pathways remains to be studied.

A potential trans-histone crosstalk related to yeast apoptosis occurs between $\mathrm{H} 2 \mathrm{~A}$ and $\mathrm{H} 3$ phosphorylation: phosphorylation of $\mathrm{H} 2 \mathrm{AS} 129$, which resembles $\mathrm{Y}-\mathrm{H} 2 \mathrm{AX}$ of higher eukaryotes [46], is increasing in yeast cells undergoing $\mathrm{H}_{2} \mathrm{O}_{2}$-induced apoptosis and it is paralleled by a decrease in phosphorylation of threonine 45 in histone $\mathrm{H} 3$ (H3T45ph) [47]. On the other hand, the function of H3T45ph in apoptotic signalling has been questioned and rather been linked to DNA replication and its absence with replicative defects [11]. Oxidative damage of DNA by menadione, a reactive quinone that as $\mathrm{H}_{2} \mathrm{O}_{2}$ generates $\mathrm{ROS}$, has furthermore been shown to lead to phosphorylation of $\mathrm{H} 2 \mathrm{~A}$ at serine 122 (H2AS122), and serine-to-alanine H2AS122A mutants have impaired survival on plates containing DSB-inducing drugs, such as methyl methanesul- fonate (MMS) or bleomycin [48], supporting the potential importance of $\mathrm{H} 2 \mathrm{~A}$ phosphorylation in apoptotic signalling during DNA damage response. However, further investigations are necessary to provide mechanistic insights.

\section{Histone H2B ubiquitination}

Another apoptosis-related modification of $\mathrm{H} 2 \mathrm{~B}$ is its ubiquitination (Fig. 1). $\mathrm{H} 2 \mathrm{~B}$ is monoubiquitinated (H2Bub1) at $\mathrm{K} 123$, which, in S. cerevisiae, is mediated by the macromolecular complex containing the E2-conjugating enzyme Rad6 and the E3 ligase Bre1 (Table 1) [49-51]. H2Bub1 has been linked to transcriptional activation and elongation and BRE1 disruption or lysine-to-arginine substitution at K123 of H2B (H2B-K123R) results in a complex phenotype that includes failures in gene activation [52-55] and lack of telomeric silencing [56-59]. H2Bub1 is important for nucleosome stability [60], it marks exon-intron structure in budding yeast [61] and prevents heterochromatin spreading [62], and it is implicated in DNA repair and checkpoint activation after DNA damage $[63,64]$ and during meiosis [65]. The function of H2Bub1 and Bre1 and its homologues in transcription regulation and DNA damage response appears conserved across evolution [66-70]. In human cells and in Drosophila it was furthermore shown that H2Bub1 is facilitated by $\mathrm{O}$-linked $\mathrm{N}$-acetylglucosamine modification of

TABLE 1. Histone modifications involved in aging and apoptotic processes in yeast.

\begin{tabular}{|c|c|c|c|c|c|}
\hline Histone & Modification & Writer & Eraser & Implication & Reference \\
\hline $\mathrm{H} 2 \mathrm{~A}$ & S122 phosphorylation & & & $\mathrm{H}_{2} \mathrm{O}_{2}$ & {$[48]$} \\
\hline $\mathrm{H} 2 \mathrm{~A}$ & S129 phosphorylation & Mec1, Tel1 & PPH3 & $\mathrm{H}_{2} \mathrm{O}_{2}$ & {$[152,153]$} \\
\hline $\mathrm{H} 2 \mathrm{~B}$ & S10 phosphorylation & Ste20 & & $\mathrm{H}_{2} \mathrm{O}_{2}$ & {$[30]$} \\
\hline $\mathrm{H} 2 \mathrm{~B}$ & K11 acetylation & & Hos3 & $\mathrm{H}_{2} \mathrm{O}_{2}$ & {$[31]$} \\
\hline $\mathrm{H} 2 \mathrm{~B}$ & K123 ubiquitination & Rad6/Bre1 & Ubp10, Ubp8 & $\mathrm{CLS}, \mathrm{RLS}, \mathrm{H}_{2} \mathrm{O}_{2}$ & {$[32,35,49,50,53,72,73]$} \\
\hline $\mathrm{H} 3$ & K4 methylation & Set1/COMPASS & Jhd2 & CLS, RLS, $\mathrm{H}_{2} \mathrm{O}_{2}$ & {$[33,35,57,121,154,155]$} \\
\hline H3 & K36 methylation & Set2 & Jhd1 & RLS & {$[124,143,156]$} \\
\hline H3 & K79 methylation & Dot1 & & RLS & {$[33,129]$} \\
\hline $\mathrm{H} 3$ & T45 phosphorylation & AKT1, 2 & & $\mathrm{H}_{2} \mathrm{O}_{2}$ & {$[47,157]$} \\
\hline H3 & K9 acetylation & Gcn5 & & CLS & {$[161,164]$} \\
\hline $\mathrm{H} 3$ & K14 acetylation & Sas3 & Hos3 & CLS & {$[161,164]$} \\
\hline H3 & K18 acetylation & Gcn5 & & CLS & {$[161,164]$} \\
\hline H3 & K56 acetylation & Asf1, Rtt109 & Hst3, Hst4 & RLS & {$[91,152,153,158]$} \\
\hline $\mathrm{H} 4$ & K16 acetylation & Sas2 & Sir2 & RLS & {$[87,159,160]$} \\
\hline
\end{tabular}

The implications listed are referring to the respective histone modifications. The listed writers and erasers may have impact on other histone modifications not related to cell death as well and the modifiers may have targets other than the histones, which may implicate them in other cell death pathways. 
$\mathrm{H} 2 \mathrm{~B}$ at $\mathrm{S} 112$ [71].

The DNA damage response machinery is closely linked to apoptosis in yeast and higher eukaryotes [14]. The observation that a loss of the ubiquitin-specific protease $U B P 10$, which is involved in cleaving the ubiquitin moiety from H2B (Table 1) [72, 73], activates the yeast metacaspase Yca1 and apoptosis [74], were first hints that H2B ubiquitination may in fact be involved in the regulation of yeast apoptosis. The finding that enhanced expression of Bre1 protected yeast cells from $\mathrm{H}_{2} \mathrm{O}_{2}$-induced cell death, whereas deletion of BRE1 potentiated cell death verified this notion [32].

During chronological aging, cells lacking bre1 show shortened lifespan that coincides with the appearance of typical apoptotic markers, such as DNA fragmentation and accumulation of ROS. The ability of Bre1 to reduce cell death is conferred by its E3 ubiquitin ligase activity mediated by its C-terminal zinc-binding RING finger domain [50]. RING domains are frequently found in E3 ubiquitin ligases and required for catalysing the transfer of ubiquitin from the E2 to the substrate [75]. $\Delta b r e 1$ cells complemented with a RING finger mutant of Bre1 (C648G, C651G) lack H2Bub1 and exhibited increased apoptosis sensitivity similar to $\Delta b r e 1$ cells, whereas the complementation of $\Delta b r e 1$ cells with a functional Bre1 made the cells behave like wildtype [32]. Furthermore, H2B-K123R mutant cells, which too lack H2Bub1, have an increased sensitivity to apoptotic stimuli, exactly as $\Delta b r e 1$ cells.

Yeast cells deficient for ubp10 display markers of apoptosis, such as DNA fragmentation, as well as enhanced expression of stress-responsive genes as compared to wild type [76]. The increased sensitivity to apoptosis observed in both $\Delta b r e 1$ and $\Delta u b p 10$ strains is associated with an increase in the activity of Yca1, while deletion of yca1 restored the wild-type phenotype [32, 74]. Deletion of Silencing Information Regulator 2 (Sir2), a NAD -dependent HDAC that amongst a plethora of targets predominately removes acetyl groups from K16 of histone H4 (Table 1) [77], could partially rescue the transcriptional pattern and abrogate the apoptotic effects of $\triangle u b p 10$ cells, suggesting that increased YCA1 expression may result from inappropriate localization of silencing complexes upon failed deubiquitination of $\mathrm{H} 2 \mathrm{~B}[72,73,76]$.

$\mathrm{H} 2 \mathrm{~B}$ ubiquitination is also an important regulator of the replicative lifespan of $S$. cerevisiae: replicatively aged cells have increased $\mathrm{H} 2 \mathrm{Bub} 1$ in their telomeric heterochromatin, along with increased methylation of histone $\mathrm{H} 3$ at lysine 4 and 79 (H3K4 and H3K79; see section "Histone methylation"), respectively $[35,78]$. Yeast aging is accompanied by the loss of transcriptional silencing at the three heterochromatic regions of the yeast genome: at least at one telomere [79], at the mating type locus [80] and of rDNA [81]. A key regulator of telomeric heterochromatin and rDNA silencing is Sir2 [82-86], which is furthermore of vital importance for RLS regulation: its over-expression extends lifespan [87], while yeast cells lacking sir2 have a shorter lifespan [88]. The effect on the RLS is likely due to Sir2's ability to repress rDNA recombination [89], which in turn hampers the formation of extrachromosomal rDNA circles
[87]. The protein levels of Sir2 typically decrease during aging, which leads to increased levels of acetylated histone $\mathrm{H} 4$ at lysine 16 (Fig. 1) and a concomitant loss of histones from specific subtelomeric regions of the genome [90]. The increase in $\mathrm{H} 2 \mathrm{Bub} 1$ in replicatively aged yeast cells coincides with decreased Sir2 abundance and an increase in acetylation of histone $\mathrm{H} 4$ at K16 (H4K16ac; see section "Histone acetylation") along with much lower occupancies of $\mathrm{H} 3, \mathrm{H} 4$, or $\mathrm{H} 2 \mathrm{~B}$ at the heterochromatic regions [35]. A global loss of histones during aging was previously also observed by Feser et al. [91]. In addition to H2Bub1, also methylation of H3K4 and H3K79 are enriched in aged cells at regions proximal to telomeres [35]. Consequently deficiencies in rad6 and bre 1 and the expression of H2B-K123R cells reduce the mean lifespans of yeast cells, which is not further reduced by deletion of sir2. Together these data indicate that $\mathrm{H} 2 \mathrm{~B}$ monoubiquitination and methylation of H3K4 and K3K79 regulate replicative aging through a Sir2related pathway [35].

Regulation of apoptosis by H2Bub1 may further exist in multicellular organisms: deletion of Rfp1, the Bre1 homologue in Caenorhabditis elegans, leads to enhanced germ cell apoptosis in the worms [92] and the depletion of Bre1b, one of the two Bre1 isoforms in mice, leads to a strong increase in apoptosis frequency in different mouse cell types [93]. In higher eukaryotic cells, however, ubiquitinated $\mathrm{H} 2 \mathrm{~A}$ is the most abundant species [94-97] and might assume some of the roles ubiquitinated $\mathrm{H} 2 \mathrm{~B}$ plays in yeast. Therefore $\mathrm{H} 2 \mathrm{~A}$ deubiquitination has been linked to chromatin condensation in mitotic and apoptotic cells in higher eukaryotes and the disappearance of H2Aub1 to late apoptotic events [98]. In fact, rapid and extensive deubiquitination of $\mathrm{H} 2 \mathrm{~A}$ occurs in Jurkat cells undergoing apoptosis initiated by, for example, anti-Fas activating antibody, staurosporine, etoposide, doxorubicin and proteasome inhibitors [99], indicating that histone deubiquitination, either $\mathrm{H} 2 \mathrm{~A}$ or $\mathrm{H} 2 \mathrm{~B}$, is a common apoptotic trigger across evolution.

\section{Histone methylation}

Monoubiquitination of $\mathrm{H} 2 \mathrm{~B}$ is prerequisite to the di- and tri-methylation of histone $\mathrm{H} 3$ on lysine 4 (H3K4me2/3) and lysine 79 (H3K79me2/3) [59, 100, 101]. This crosstalk is unidirectional, as mutations that eliminate either $\mathrm{H} 3$ modification had no effects on the level of $\mathrm{H} 2 \mathrm{~B}$ ubiquitination [100]. H3K4 trimethylation is further regulated by monoubiquitination-independent processes: loss of H3K14 acetylation results in the specific loss of $\mathrm{H} 3 \mathrm{~K} 4 \mathrm{me}$, but not mono- or dimethylation [102] and methylation of $\mathrm{H3}$ at arginine 2 (H3R2) disables H3K4 methylation in yeast and mammalian cells [103-105]. H3K4me3 marks localize to the 5 ' end of active genes in budding yeast and are found associated with the initiated, phosphorylated form of RNA polymerase II [106-108], implicating it in transcriptional elongation. It is further not only important for transcriptional activation [109-112], but also for silencing at telomeres [112-114] and rDNA loci [57, 115, 116]. Yeast cells lacking set1 are deficient in the non-homologous end joining pathway of DSB repair and are impaired in traversing S- 
phase of the cell cycle in the presence of replication stress [117]. In fact, set1 deficient cells have a reduced replication activity [118]. H3K4 methylation is mediated by the Set1containing complex COMPASS (Table 1), which, in S. cerevisiae, consists of seven subunits [119-123] and is highly conserved among eukaryotes [61]. With respect to apoptosis it has been shown that a loss of H3K4me3 (Fig. 1) is a trigger for apoptotic cell death [33]. Strains lacking set1 (or two other members of the COMPASS complex, Spp1 and Bre2, respectively) are susceptible to Yca1-dependent apoptosis, both during chronological aging as well as in response to $\mathrm{H}_{2} \mathrm{O}_{2}$ treatment [33]. $\Delta$ set1 cells similarly have a shortened RLS [124]. Preventing loss of H3K4me3 by depleting the H3K4 demethylase Jhd 2 on the contrary prolonged the CLS of the cells [33].

H3K79me3 is mediated by the methyltransferase Dot1 (Disruptor Of Telomeric silencing 1; Table 1). Dot1 is highly conserved across evolution and appears to be the sole methyltransferase responsible for H3K79 methylation [125130]. H3K79 methylation is essential for efficient silencing near telomeres, rDNA loci, and the yeast mating type loci [113], for precise DDR [63, 131-134], and in higher eukaryotes for transcriptional control of developmental genes, such as HOXA9 [108, 135] and Wnt target genes [136]. Contrary to H2Bub1 and H3K4me3, H3K79me3, however, appears to play no primary role in apoptotic signalling in yeast: deletion of dot1 only slightly improves survival of wild-type cells, but it rescues $\Delta$ set 1 cells from apoptotic death [33]. Furthermore, the DNA damage checkpoint kinase Rad9 and the yeast homolog of endonuclease G, Nuc1, are critical for cell death of $\Delta$ set1 cells, suggesting that loss of $\mathrm{H} 3 \mathrm{~K} 4$ methylation in the presence of $\mathrm{H} 3 \mathrm{~K} 79$ methylation and the kinase Rad9 enhances chromatin accessibility to endonuclease digestion. Importantly, wild-type, but not dot1 $\Delta$ cells, loose H3K4 methylation during chronological aging, which coincides with a shorter lifespan and indicates that the loss of H3K4 methylation in fact acts as important trigger for apoptotic cell death [33].

A link between apoptosis and H3K4me was also observed in other species, although data here are somewhat controversial: while deficiency in MLL1, one of several H3K4 methyltransferases in mammals [137], and a lack of H3K4me3 was enhancing apoptosis induced by ER-stress [138], H3K4me3 recognition was necessary to stimulate DNA-repair after UV irradiation and to promote DNAdamage- $[139,140]$ or genotoxic stress-induced apoptosis [141], indicating that regulation of apoptosis by H3K4 methylation may occur in a context- and/or tissue-specific manner.

As outlined above, replicatively aged cells have increased H2Bub1, H3K4me, and H3K79me in their telomeric heterochromatin, which is accompanied by the loss of transcriptional silencing at the telomeres. The antisilencing activity of $\mathrm{H} 2 \mathrm{Bub}, \mathrm{H} 3 \mathrm{~K} 4 \mathrm{me}$, and H3K79me at telomeric regions is opposed by another histone methyltransferase: Set2 [35, 124]. Set2 mediates methylation of $\mathrm{H} 3$ at $\mathrm{K} 36$ (Table 1) $[142,143]$, which occurs independent of H2Bub1 [100, 144]. Methylated H3K36 has been implicated in transcriptional elongation and H3K36me3 is typi- cally found to accumulate at the 3 'end of active genes in association with the phosphorylated elongating form of RNA polymerase II [142, 145-147]. The anti-silencing function of Set2 was observed at all three heterochromatic regions in yeast and set2-depleted cells have a prolonged RLS as compared to wild-type cells $[35,124]$. Contrary to yeast, loss of H3K36me 3 and deletion of the mediating methyltransferase met-1 shortened the lifespan of the nematode C. elegans [148], whereas loss of H3K4me3 is prolonging it [155], further supporting the contextdependency of histone modifications.

\section{Histone acetylation}

As outlined above, normal aging of yeast cells is accompanied by a profound loss of histone proteins [91]. The removal of histones from DNA and the incorporation of histones onto DNA are mediated by so-called histone chaperones. A highly conserved central chaperone of histones $\mathrm{H} 3$ and $\mathrm{H} 4$ is Antisilencing function 1 (Asf1), which is required for proper regulation of gene expression, acetylation of $\mathrm{H} 3$ on K56 (H3K56ac; Table 1), and the maintenance of genomic integrity [149-151]. Deletion of asf1 results in a very short CLS and a median RLS of only about 7 generations in comparison to the median life span of about 27 generations for wild-type yeast and of 15 generations for sir2 mutants [91]. Yeast lacking both asf1 and sir2 are extremely short lived with a median lifespan of 4 to 5 generations, which demonstrates that Asf1 and Sir2 are acting independently to promote longevity.

The role of Asf1 in determining a normal lifespan is mediated via acetylation of H3K56, which is mediated by the histone acetyltransferase (HAT) Rtt109 (Table 1) [152]. In lifespan regulation Asf1 and Rtt109 act together and a H3K56Q mutant, which mimics acetylation, has a greatly shortened lifespan. Similarly, yeast strains lacking the two redundant histone deacetylases Hst3 and Hst4 (Table 1), which leads to elevated levels of H3K56ac [153, 154], die early, indicating that $\mathrm{H} 3 \mathrm{~K} 56 \mathrm{ac}$ levels need to be tightly regulated [91]. H3K56ac levels appear to administer histone gene expression, which is repressed by the histone information regulator (HIR) complex $[155,156]$. Consequently, overexpression of the four core histones extends the median lifespan of asf 1 mutants by $65 \%$ and inactivation of any component of the Hir complex (Hir1, Hir2, Hir3, Hir4, respectively) extends the median RLS of yeast cells by $25 \%-35 \%$. On the contrary, overexpression of HIR1 suppressed mRNA-instability induced apoptosis of yeast cells lacking a functional LSM4, a component of the U6 snRNA complex, during chronological aging, coinciding with a prolonged CLS [157]. How alterations in Hir proteins lead to lifespan extension on a mechanistic level remains to be seen, but it appears to be via a pathway that is independent of known lifespan regulators, such as Sir2 and the TOR pathway [91]. Interestingly, however, the loss of core histones is also directly correlated to aging of primary human fibroblasts [158].

Dying $\Delta a s f 1$ cells not only show marks of apoptosis, but also of necrosis and they accumulate a multitude of autophagic bodies [159]. Autophagy (also called macroau- 
tophagy) is an evolutionary conserved process important for human health by which cytoplasmic contents, such as damaged organelles or aggregated proteins, are degraded by the lysosome/vacuole. Autophagy is primarily a prosurvival process, but it can also contribute to cell death, and it is becoming increasingly clear that the transcriptional regulation of autophagy-related genes is partially controlled by histone modifications and that this serves as a key determinant of survival versus death decision in autophagic cells [160]. Key in this context appears to be the loss of $\mathrm{H} 3$ and/or $\mathrm{H} 4$ acetylation, in yeast as well as in higher eukaryotes.

First evidence therefor came from studies on chronologically aged cells: chronologically aging and dying yeast cells show a decline in the levels of polyamines, a typical hallmark of aging across evolution [161-163]. Treating wildtype yeast cells with the exogenous polyamide spermidine extended the CLS due to deacetylation of histone H3 at K9, $\mathrm{K} 14$, and K18 through the inhibition of HATs, which coincided with suppression of oxidative stress and necrotic cell death [161]. The altered acetylation status of histone H3 led to a significant up-regulation of autophagy-related genes and consequently autophagy activation, not only in aging yeast, but also in Drosophila, C. elegans, and human cells [161]. Hyperacetylation of H3 at K14 and K18, but not $\mathrm{K} 9$, due to defects in acetate metabolism on the contrary led to a dramatically reduced CLS of yeast cells, which appeared to be due to the inability of the yeast mutants to induce autophagy $[164,165]$. This negative effect of hyperacteylated $\mathrm{H} 3$ on cellular aging appears conserved across species $[164,165]$.

The critical linkage between histone modifications, the transcriptional regulation of autophagy-related genes and cell death is further supported by the observation that a decrease in H4K16ac due to the down-regulation of the HAT hMOF emerged from the induction of autophagy in distinct mammalian cell lines [166]. Similarly, the expression of Sas2, the yeast homolog of hMOF, and H4K16ac levels were found repressed upon autophagy induction in yeast $[160,166]$. The inhibition of H4K16 deacetylation in mammalian cells did not inhibit autophagy, but increased the autophagic flux, whereas reduced H4K16ac was accompanied by the down-regulation of a large number of autophagy-related genes $[160,166]$. Alongside with the reduction of $\mathrm{H} 4 \mathrm{~K} 16 \mathrm{ac}$ also $\mathrm{H} 3 \mathrm{~K} 4 \mathrm{me} 3$ is decreased upon autophagy induction in a wide variety of cells from yeast to higher eukaryotes, which may contribute to a general transcriptional inhibition to save energy during prolonged starvation [160]. Antagonizing H4K16 deacetylation by overexpressing of hMOF or by inhibiting the HDAC SIRT1, which has H4K16 as its primary histone target, resulted in increased cell death upon autophagy-induction [160, 166]. In a screen using a library of histone $\mathrm{H} 3-\mathrm{H} 4$ yeast mutants, acetylation of $\mathrm{H} 3 \mathrm{~K} 56$ was further found reduced in cells treated with the TOR-inhibitor rapamycin, which was proposed to result from the TOR-dependent repression of the H3K56 HDACs Hst3 and Hst4 [167]. How this relates to programmed cell death remains to be seen.
POTENTIAL DOWNSTREAM MECHANISMS OF EPIGENETIC REGULATION DURING CELL DEATH

While it is without any doubt that histone modifications are critical regulators of cell survival and death, it is only poorly understood how they and the coinciding chromatin rearrangements do so on a mechanistic level. The most obvious process influenced by alterations in histone modifications is transcription (Fig. 2).

In this context it has been shown that altered $\mathrm{H} 2 \mathrm{~B}$ ubiquitination in $\triangle b r e 1$ and $\triangle u b p 10$ cells led to the enhanced expression of YCA1, likely due to the inappropriate localization of silencing complexes [34, 72, 73, 76]. H2B ubiquitination also plays a role in p53-mediated apoptosis in human cells, although rather indirectly: knockdown of the EHF transcription factor induced p53-dependent apoptosis, whereas its overexpression is required for the survival of p53-positive colon cancer cells [168]. EHF directly activates the transcription of RUVBL1, an ATPase associated with chromatin-remodeling complexes. RUVBL1 represses transcription of $\mathrm{p} 53$ and its target genes by binding to the p53 promoter, as well as by interfering with RNF20/hBRE1-mediated H2B monoubiquitination and by promoting trimethylation of $\mathrm{H} 3$ at $\mathrm{K} 9$ (H3K9me3), a transcriptional silencing mark [168]. In leukaemia cells, it was furthermore shown that inhibition of DOT1L, the sole human homolog of yeast Dot1, and H3K79 methylation increased apoptosis due to down-regulation of antiapoptotic BCL2L1 [169]. Yeast cells lacking RTT109 or ASF1 and consequently H3K56 acetylation are characterized by the repression of cell cycle genes and an accumulation of cells with in G2/M phase of the cell cycle [91], whereas H4K16 acetylation is, across species, important for the transcriptional regulation of autophagy-related genes and the subsequent survival versus death response $[160,166]$. Also, ribosomal DNA silencing is affected by changes in H4K16ac [77, 84, 86, 87, 91], which may lead to nucleolar stress and an apoptotic response [170]. Together these data indicate that altered histone modifications can directly influence apoptosis due to deregulated transcription of key apoptosis regulatory proteins and indirectly due to deregulation of, for example, cell cycle, autophagy, and ribosomal genes.

Impaired DNA DSB repair and replication defects are other nuclear processes that are influenced by histone modifications and might link them to apoptosis (Fig. 2). For example, H2B ubiquitination is required for Rad9-mediated checkpoint activation after DNA damage and Rad51dependent DNA repair in yeast $[63,64]$ and similarly H3K4 and $\mathrm{H} 3 \mathrm{~K} 79$ methylation have been implicated in DNA repair as well as DNA replication and recombination [171, 172]. Indeed yeast cells lacking set1 and H3K4me have impaired DSB repair and are accumulating mutations [33], as well as replication defects [118], but it remains to be seen if this is related to the increase in apoptotic death of these cells.

Another, rather unexpected regulatory mechanism that is influenced by histone modifications appears to be altered nucleocytoplasmic localization (Fig. 2). In HeLa cells it 


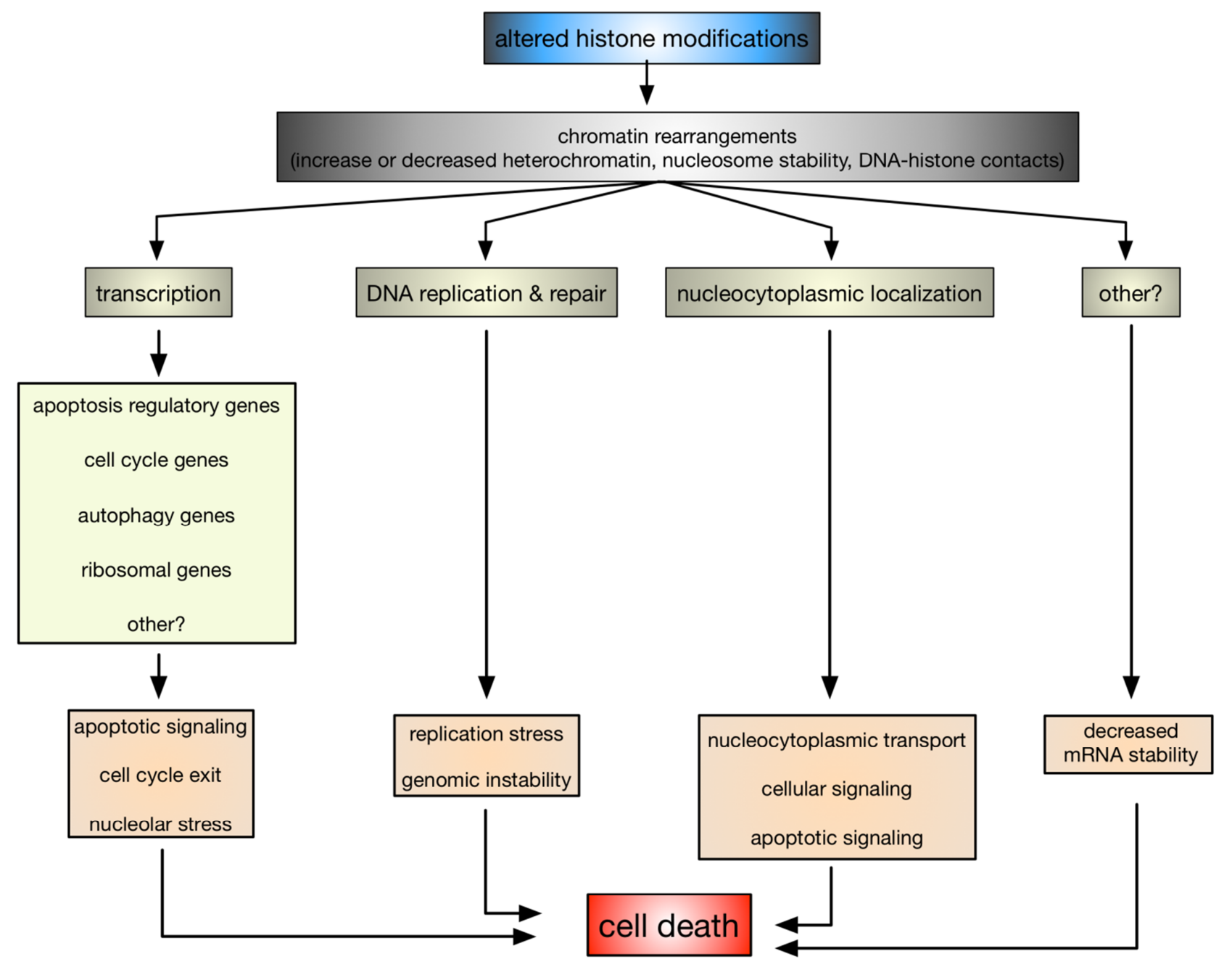

FIGURE 2: Schematic presentation as to how altered histone modifications might promote cell death. Changes in histone modifications will lead to structural rearrangements in the chromatin, which in turn will affect processes, such as transcription, DNA replication and repair, nucleocytoplasmic localization of proteins. Altered transcription may change the expression of regulatory apoptotic factors, cell cycle, autophagy, ribosomal and other vital genes, which in turn will affect apoptotic signalling, cell cycle progression and/or ribosome biogenesis, which may lead to cell death. Replication stress, genomic and mRNA instability, defects in nucleocytoplasmic transport as well as other vital signalling pathways may also lead to cell death as a consequence of altered histone marks.

was shown that cytochrome $c$, released from mitochondria upon apoptosis induction, is translocating into the nucleus, where it specifically binds acetylated H2A [173]. Nuclear, H2Aac-bound cytochrome $c$ is causing chromatin condensation and further potentiating apoptosis [173]. The ING (Inhibitor of Growth) family of tumor suppressors acts as readers and writers of histone modifications and ING1 is a reader of H3K4me3 [139]. ING1 is a nuclear and nucleolar protein, where it exhibits apoptotic functions, and it translocates to mitochondria of primary human fibroblasts and epithelial cell lines in response to apoptosis stimuli [174]. ING1 harbors a BH3-like domain due to which it can bind pro-apoptotic Bax and promote mitochondrial membrane permeability [174]. In mammalian cells it was further shown that H2BS14ph is directly contributing to the inactivation of survival pathways, including NF-kB, due to immobilizing the RanGEF RCC1 on chromatin, thereby reducing nuclear RanGTP levels and inactivating nucleocytoplasmic transport [11].

\section{CONCLUSION}

Apoptotic cell death is accompanied by pronounced structural rearrangements within the cell, including chromatin architecture. Accumulating evidence points towards an epigenetic regulation of the chromatin remodelling events. A key player in this context appears to be monoubiquitination of histone $\mathrm{H} 2 \mathrm{~B}$ : it shelters yeast cells against intrinsic and extrinsic death stimuli. $\mathrm{H} 2 \mathrm{~B}$ monoubiquitination is prerequisite for methylation of histone H3K4 and H3K79, respectively, and $\mathrm{H} 3 \mathrm{~K} 4$ methylation appears as another vitally essential histone mark, whereas the role of H3K79 methylation is less clear. Importantly, the same histone modifications seemingly decide on the fate of higher eukaryotic cells, although context- and tissue-specific vari- 
ances contribute to and complicate the particular decision. Nevertheless, these studies show that beyond the conservation of the apoptotic core machinery in yeast, also intrinsic triggers of cell death are conserved. Future studies are needed to further dissect the death code of yeast cells and most importantly to further identify and characterize the up- and downstream players that transmit the signals to and from the nucleus.

\section{ACKNOWLEDGMENTS}

This work was supported by grants from the Fonds Nationale de Recherche Scientifique (FNRS) Belgium (grant T.0237.13), the Fédération Wallonie-Bruxelles (ARC 4.110.F.000092F), the Fonds Brachet and the Fonds Van Buuren.

\section{REFERENCES}

1. Fadeel B, Orrenius S (2005). Apoptosis: a basic biological phenomenon with wide-ranging implications in human disease. Journal of internal medicine 258(6): 479-517.

2. Kerr JF, Wyllie AH, Currie AR (1972). Apoptosis: a basic biological phenomenon with wide-ranging implications in tissue kinetics. $\mathbf{B r} \mathbf{J}$ Cancer 26(4): 239-257. PMID: 4561027

3. Wyllie $\mathrm{AH}$ (1980). Glucocorticoid-induced thymocyte apoptosis is associated with endogenous endonuclease activation. Nature 284(5756): 555-556. PMID: 6245367

4. Olins $D E$, Olins AL (2003). Chromatin history: our view from the bridge. Nat Rev Mol Cell Biol 4(10): 809-814.

5. Luger K, Dechassa ML, Tremethick DJ (2012). New insights into nucleosome and chromatin structure: an ordered state or a disordered affair? Nat Rev Mol Cell Biol 13(7): 436-447.

6. Bannister AJ, Kouzarides $T$ (2011). Regulation of chromatin by histone modifications. Cell Res 21(3): 381-395.

7. Singh RK, Gunjan A (2011). Histone tyrosine phosphorylation comes of age. Epigenetics 6(2): 153-160.

8. Fullgrabe J, Hajji N, Joseph B (2010). Cracking the death code: apoptosis-related histone modifications. Cell Death Differ 17(8): 12381243.

9. Rockenfeller P, Madeo $F$ (2008). Apoptotic death of ageing yeast. Exp Gerontol 43(10): 876-881.

10. Carmona-Gutierrez D, Eisenberg T, Buttner S, Meisinger C, Kroemer G, Madeo F (2010). Apoptosis in yeast: triggers, pathways, subroutines. Cell Death Differ 17(5): 763-773.

11. Corte-Real M, Madeo F (2013). Yeast programed cell death and aging. Frontiers in oncology $3(283$.

12. Fabrizio P, Longo VD (2003). The chronological life span of Saccharomyces cerevisiae. Aging Cell 2(2): 73-81. PMID: 12882320

13. Kaeberlein $M$ (2010). Lessons on longevity from budding yeast. Nature 464(7288): 513-519.

14. Walter D, Wissing S, Madeo F, Fahrenkrog B (2006). The inhibitorof-apoptosis protein Bir1p protects against apoptosis in S. cerevisiae and is a substrate for the yeast homologue of Omi/HtrA2. J Cell Sci 119(Pt 9): 1843-1851.

15. Madeo F, Herker E, Maldener C, Wissing S, Lachelt S, Herlan M, Fehr M, Lauber K, Sigrist SJ, Wesselborg S, Frohlich KU (2002). A caspase-related protease regulates apoptosis in yeast. Mol Cell 9(4): 911-917.

\section{CONFLICT OF INTEREST}

The author declares no conflict of interest.

\section{COPYRIGHT}

(C) 2015 Fahrenkrog. This is an open-access article released under the terms of the Creative Commons Attribution (CC BY) license, which allows the unrestricted use, distribution, and reproduction in any medium, provided the original author and source are acknowledged.

Please cite this article as: Birthe Fahrenkrog (2015). Histone modifications as regulators of life and death in Saccharomyces cerevisiae. Microbial Cell 3(1): 1-13. doi: 10.15698/mic2016.01.472

16. Belanger $K D$, Walter $D$, Henderson $T A$, Yelton $A L, O$ 'Brien TG, Belanger KG, Geier SJ, Fahrenkrog B (2009). Nuclear localisation is crucial for the proapoptotic activity of the HtrA-like serine protease Nma111p. J Cell Sci 122(Pt 21): 3931-3941.

17. Hill SM, Hao X, Liu B, Nystrom T (2014). Life-span extension by a metacaspase in the yeast Saccharomyces cerevisiae. Science 344(6190): 1389-1392.

18. Herker $E$, Jungwirth $H$, Lehmann KA, Maldener C, Frohlich KU, Wissing S, Buttner S, Fehr M, Sigrist S, Madeo F (2004). Chronological aging leads to apoptosis in yeast. J Cell Biol 164(4): 501-507.

19. Buttner S, Eisenberg T, Carmona-Gutierrez D, Ruli D, Knauer $H$, Ruckenstuhl C, Sigrist C, Wissing S, Kollroser M, Frohlich KU, Sigrist S, Madeo $F$ (2007). Endonuclease $G$ regulates budding yeast life and death. Mol Cell 25(2): 233-246.

20. Wissing S, Ludovico P, Herker E, Buttner S, Engelhardt SM, Decker T, Link A, Proksch A, Rodrigues F, Corte-Real M, Frohlich KU, Manns J, Cande C, Sigrist SJ, Kroemer G, Madeo F (2004). An AIF orthologue regulates apoptosis in yeast. J Cell Biol 166(7): 969-974.

21. Buttner S, Ruli D, Vogtle FN, Galluzzi L, Moitzi B, Eisenberg T, Kepp O, Habernig L, Carmona-Gutierrez D, Rockenfeller P, Laun P, Breitenbach $M$, Khoury C, Frohlich KU, Rechberger G, Meisinger C, Kroemer G, Madeo $F$ (2011). A yeast BH3-only protein mediates the mitochondrial pathway of apoptosis. EMBO J 30(14): 2779-2792.

22. Fahrenkrog B, Sauder U, Aebi U (2004). The S. cerevisiae HtrA-like protein Nma111p is a nuclear serine protease that mediates yeast apoptosis. J Cell Sci 117(Pt 1): 115-126.

23. Laun P, Pichova A, Madeo F, Fuchs J, Ellinger A, Kohlwein S, Dawes I, Frohlich KU, Breitenbach M (2001). Aged mother cells of Saccharomyces cerevisiae show markers of oxidative stress and apoptosis. Mol Microbiol 39(5): 1166-1173.

24. Ahn SH, Cheung WL, Hsu JY, Diaz RL, Smith MM, Allis CD (2005). Sterile 20 kinase phosphorylates histone $\mathrm{H} 2 \mathrm{~B}$ at serine 10 during hydrogen peroxide-induced apoptosis in S. cerevisiae. Cell 120(1): 2536.

25. Ahn SH, Diaz RL, Grunstein M, Allis CD (2006). Histone H2B deacetylation at lysine 11 is required for yeast apoptosis induced by phosphorylation of H2B at serine 10. Mol Cell 24(2): 211-220.

26. Walter D, Matter A, Fahrenkrog B (2010). Bre1p-mediated histone $\mathrm{H} 2 \mathrm{~B}$ ubiquitylation regulates apoptosis in Saccharomyces cerevisiae. J Cell Sci 123(Pt 11): 1931-1939. 
27. Walter D, Matter A, Fahrenkrog B (2014). Loss of histone H3 methylation at lysine 4 triggers apoptosis in Saccharomyces cerevisiae. PLoS Genet 10(1): e1004095.

28. Wright DE, Wang CY, Kao CF (2011). Flickin' the ubiquitin switch: the role of $\mathrm{H} 2 \mathrm{~B}$ ubiquitylation in development. Epigenetics 6(10): 1165-1175.

29. Rhie BH, Song YH, Ryu HY, Ahn SH (2013). Cellular aging is associated with increased ubiquitylation of histone $\mathrm{H} 2 \mathrm{~B}$ in yeast telomeric heterochromatin. Biochem Biophys Res Commun 439(4): 570-575.

30. Rogakou EP, Nieves-Neira W, Boon C, Pommier Y, Bonner WM (2000). Initiation of DNA fragmentation during apoptosis induces phosphorylation of H2AX histone at serine 139. J Biol Chem 275(13): 9390-9395.

31. Cheung WL, Ajiro K, Samejima K, Kloc M, Cheung $P$, Mizzen CA, Beeser A, Etkin LD, Chernoff J, Earnshaw WC, Allis CD (2003). Apoptotic phosphorylation of histone $\mathrm{H} 2 \mathrm{~B}$ is mediated by mammalian sterile twenty kinase. Cell 113(4): 507-517.

32. Ajiro $K$ (2000). Histone $H 2 B$ phosphorylation in mammalian apoptotic cells. An association with DNA fragmentation. J Biol Chem 275(1): 439-443.

33. Fernandez-Capetillo $O$, Allis CD, Nussenzweig A (2004). Phosphorylation of histone $\mathrm{H} 2 \mathrm{~B}$ at DNA double-strand breaks. J Exp Med 199(12): 1671-1677.

34. Ajiro K, Scoltock AB, Smith LK, Ashasima M, Cidlowski JA (2010). Reciprocal epigenetic modification of histone $\mathrm{H} 2 \mathrm{~B}$ occurs in chromatin during apoptosis in vitro and in vivo. Cell Death Differ 17(6): 984-993.

35. Suka N, Suka Y, Carmen AA, Wu J, Grunstein M (2001). Highly specific antibodies determine histone acetylation site usage in yeast heterochromatin and euchromatin. Mol Cell 8(2): 473-479.

36. Wong CH, Chan H, Ho CY, Lai SK, Chan KS, Koh CG, Li HY (2009). Apoptotic histone modification inhibits nuclear transport by regulating RCC1. Nat Cell Biol 11(1): 36-45.

37. Gorlich D, Pante N, Kutay U, Aebi U, Bischoff FR (1996). Identification of different roles for RanGDP and RanGTP in nuclear protein import. EMBO J 15(20): 5584-5594. PMID: 8896452.

38. Melchior F, Paschal B, Evans J, Gerace L (1993). Inhibition of nuclear protein import by nonhydrolyzable analogues of GTP and identification of the small GTPase Ran/TC4 as an essential transport factor. J Cell Biol 123(6 Pt 2): 1649-1659. PMID: 8276887

39. Moore MS, Blobel G (1993). The GTP-binding protein Ran/TC4 is required for protein import into the nucleus. Nature 365(6447): 661663.

40. van Attikum H, Fritsch O, Hohn B, Gasser SM (2004). Recruitment of the INO80 complex by H2A phosphorylation links ATP-dependent chromatin remodeling with DNA double-strand break repair. Cell 119(6): 777-788.

41. Baker SP, Phillips J, Anderson S, Qiu Q, Shabanowitz J, Smith MM, Yates JR, 3rd, Hunt DF, Grant PA (2010). Histone H3 Thr 45 phosphorylation is a replication-associated post-translational modification in S. cerevisiae. Nat Cell Biol 12(3): 294-298.

42. Robzyk K, Recht J, Osley MA (2000). Rad6-dependent ubiquitination of histone H2B in yeast. Science 287(5452): 501-504.

43. Hwang WW, Venkatasubrahmanyam S, lanculescu AG, Tong A, Boone C, Madhani HD (2003). A conserved RING finger protein required for histone $\mathrm{H} 2 \mathrm{~B}$ monoubiquitination and cell size control. Mol Cell 11(1): 261-266.
44. Wood A, Schneider J, Dover J, Johnston M, Shilatifard A (2003). The Paf1 complex is essential for histone monoubiquitination by the Rad6-Bre1 complex, which signals for histone methylation by COMPASS and Dot1p. The Journal of biological chemistry 278(37): 34739-34742.

45. Kao CF, Hillyer C, Tsukuda T, Henry K, Berger S, Osley MA (2004). Rad6 plays a role in transcriptional activation through ubiquitylation of histone H2B. Genes \& development 18(2): 184-195.

46. Henry KW, Wyce A, Lo WS, Duggan LJ, Emre NC, Kao CF, Pillus L, Shilatifard A, Osley MA, Berger SL (2003). Transcriptional activation via sequential histone $\mathrm{H} 2 \mathrm{~B}$ ubiquitylation and deubiquitylation, mediated by SAGA-associated Ubp8. Genes \& development 17(21): 2648-2663.

47. Wyce A, Xiao T, Whelan KA, Kosman C, Walter W, Eick D, Hughes TR, Krogan NJ, Strahl BD, Berger SL (2007). H2B Ubiquitylation Acts as a Barrier to Ctk1 Nucleosomal Recruitment Prior to Removal by Ubp8 within a SAGA-Related Complex. 27(2): 275-288.

48. Xiao T, Kao CF, Krogan NJ, Sun ZW, Greenblatt JF, Osley MA, Strahl $\mathrm{BD}$ (2005). Histone $\mathrm{H} 2 \mathrm{~B}$ ubiquitylation is associated with elongating RNA polymerase II. Molecular and cellular biology 25(2): 637-651.

49. Dover J, Schneider J, Tawiah-Boateng MA, Wood A, Dean K, Johnston M, Shilatifard A (2002). Methylation of histone H3 by COMPASS requires ubiquitination of histone $\mathrm{H} 2 \mathrm{~B}$ by Rad6. The Journal of biological chemistry $277(32)$ : 28368-28371.

50. Briggs SD, Bryk M, Strahl BD, Cheung WL, Davie JK, Dent SY, Winston F, Allis CD (2001). Histone H3 lysine 4 methylation is mediated by Set1 and required for cell growth and rDNA silencing in Saccharomyces cerevisiae. Genes Dev 15(24): 3286-3295.

51. Mutiu Al, Hoke SM, Genereaux J, Liang G, Brandl CJ (2007). The role of histone ubiquitylation and deubiquitylation in gene expression as determined by the analysis of an HTB1(K123R) Saccharomyces cerevisiae strain. Mol Genet Genomics 277(5): 491-506.

52. Sun ZW, Allis CD (2002). Ubiquitination of histone H2B regulates H3 methylation and gene silencing in yeast. Nature 418(6893): 104108.

53. Chandrasekharan MB, Huang F, Sun ZW (2009). Ubiquitination of histone $\mathrm{H} 2 \mathrm{~B}$ regulates chromatin dynamics by enhancing nucleosome stability. Proc Natl Acad Sci U S A 106(39): 16686-16691.

54. Shieh GS, Pan CH, Wu JH, Sun YJ, Wang CC, Hsiao WC, Lin CY, Tung L, Chang TH, Fleming AB, Hillyer C, Lo YC, Berger SL, Osley MA, Kao CF (2011). H2B ubiquitylation is part of chromatin architecture that marks exon-intron structure in budding yeast. BMC genomics 12(627.

55. Ma MK, Heath C, Hair A, West AG (2011). Histone crosstalk directed by $\mathrm{H} 2 \mathrm{~B}$ ubiquitination is required for chromatin boundary integrity. PLoS Genet 7(7): e1002175.

56. Giannattasio M, Lazzaro F, Plevani P, Muzi-Falconi M (2005). The DNA damage checkpoint response requires histone $\mathrm{H} 2 \mathrm{~B}$ ubiquitination by Rad6-Bre1 and H3 methylation by Dot1. J Biol Chem 280(11): 98799886 .

57. Game JC, Williamson MS, Spicakova T, Brown M (2006). The RAD6/BRE1 histone modification pathway in Saccharomyces confers radiation resistance through a RAD51-dependent process that is independent of RAD18. Genetics 137(4): 1951-1968.

58. Yamashita K, Shinohara M, Shinohara A (2004). Rad6-Bre1mediated histone $\mathrm{H} 2 \mathrm{~B}$ ubiquitylation modulates the formation of double-strand breaks during meiosis. Proc Natl Acad Sci U S A 101(31): 11380-11385.

59. Bray S, Musisi H, Bienz M (2005). Bre1 is required for Notch signaling and histone modification. Dev Cell 8(2): 279-286. 
60. Chernikova SB, Dorth JA, Razorenova OV, Game JC, Brown JM (2010). Deficiency in Bre1 impairs homologous recombination repair and cell cycle checkpoint response to radiation damage in mammalian cells. Radiation research 174(5): 558-565.

61. Kim J, Hake SB, Roeder RG (2005). The human homolog of yeast BRE1 functions as a transcriptional coactivator through direct activator interactions. Mol Cell 20(5): 759-770.

62. Wood A, Krogan NJ, Dover J, Schneider J, Heidt J, Boateng MA, Dean K, Golshani A, Zhang Y, Greenblatt JF, Johnston M, Shilatifard A (2003). Bre1, an E3 ubiquitin ligase required for recruitment and substrate selection of Rad6 at a promoter. Mol Cell 11(1): 267-274.

63. Zhu B, Zheng $Y$, Pham AD, Mandal SS, Erdjument-Bromage $H$, Tempst $P$, Reinberg $D$ (2005). Monoubiquitination of human histone $\mathrm{H} 2 \mathrm{~B}$ : the factors involved and their roles in HOX gene regulation. Mol Cell 20(4): 601-611.

64. Fujiki R, Hashiba W, Sekine H, Yokoyama A, Chikanishi T, Ito S, Imai Y, Kim J, He HH, Igarashi K, Kanno J, Ohtake F, Kitagawa H, Roeder RG, Brown M, Kato S (2011). GlcNAcylation of histone H2B facilitates its monoubiquitination. Nature 480(7378): 557-560.

65. Burhans WC, Weinberger $M$, Marchetti MA, Ramachandran L, D'Urso G, Huberman JA (2003). Apoptosis-like yeast cell death in response to DNA damage and replication defects. Mutation research 532(1-2): 227-243.

66. Emre NC, Ingvarsdottir K, Wyce A, Wood A, Krogan NJ, Henry KW, Li K, Marmorstein R, Greenblatt JF, Shilatifard A, Berger SL (2005). Maintenance of low histone ubiquitylation by Ubp10 correlates with telomere-proximal Sir2 association and gene silencing. Mol Cell 17(4): 585-594.

67. Gardner RG, Nelson ZW, Gottschling DE (2005). Ubp10/Dot4p regulates the persistence of ubiquitinated histone $\mathrm{H} 2 \mathrm{~B}$ : distinct roles in telomeric silencing and general chromatin. Mol Cell Biol 25(14): 6123-6139.

68. Bettiga M, Calzari L, Orlandi I, Alberghina L, Vai M (2004). Involvement of the yeast metacaspase Yca1 in ubp $\Delta$-programmed cell death. FEMS yeast research 5(2): 141-147.

69. Deshaies RJ, Joazeiro CA (2009). RING domain E3 ubiquitin ligases. Annual review of biochemistry 78(399-434.

70. Orlandi I, Bettiga M, Alberghina L, Vai M (2004). Transcriptional profiling of ubp10 null mutant reveals altered subtelomeric gene expression and insurgence of oxidative stress response. J Biol Chem 279(8): 6414-6425.

71. Imai S, Armstrong CM, Kaeberlein $M$, Guarente $L$ (2000). Transcriptional silencing and longevity protein Sir2 is an NADdependent histone deacetylase. Nature 403(6771): 795-800.

72. Lettre G, Kritikou EA, Jaeggi M, Calixto A, Fraser AG, Kamath RS, Ahringer J, Hengartner MO (2004). Genome-wide RNAi identifies p53dependent and -independent regulators of germ cell apoptosis in C. elegans. Cell death and differentiation 11(11): 1198-1203.

73. Chernikova SB, Razorenova OV, Higgins JP, Sishc BJ, Nicolau M, Dorth JA, Chernikova DA, Kwok S, Brooks JD, Bailey SM, Game JC, Brown JM (2012). Deficiency in mammalian histone H2B ubiquitin ligase Bre1 (Rnf20/Rnf40) leads to replication stress and chromosomal instability. Cancer Res 72(8): 2111-2119.

74. Levinger L, Varshavsky A (1982). Selective arrangement of ubiquitinated and D1 protein-containing nucleosomes within the Drosophila genome. Cell 28(2): 375-385. PMID: 6277512.

75. Davie JR, Lin R, Allis CD (1991). Timing of the appearance of ubiquitinated histones in developing new macronuclei of Tetrahymena thermophila. Biochem Cell Biol 69(1): 66-71. PMID: 1645982 .
76. Hensold JO, Swerdlow PS, Housman DE (1988). A transient increase in histone H2A ubiquitination is coincident with the onset of erythroleukemic cell differentiation. Blood 71(4): 1153-1156. PMID: 2833326.

77. Vassilev AP, Rasmussen HH, Christensen EI, Nielsen S, Celis JE (1995). The levels of ubiquitinated histone $\mathrm{H} 2 \mathrm{~A}$ are highly upregulated in transformed human cells: partial colocalization of $\mathrm{uH} 2 \mathrm{~A}$ clusters and PCNA/cyclin foci in a fraction of cells in S-phase. J Cell Sci 108 ( Pt 3)(1205-1215. PMID: 7622605

78. Marushige $Y$, Marushige $K$ (1995). Disappearance of ubiquitinated histone $\mathrm{H} 2 \mathrm{~A}$ during chromatin condensation in TGF beta 1-induced apoptosis. Anticancer research 15(2): 267-272. PMID: 7762993.

79. Mimnaugh EG, Kayastha G, McGovern NB, Hwang SG, Marcu MG, Trepel J, Cai SY, Marchesi VT, Neckers L (2001). Caspase-dependent deubiquitination of monoubiquitinated nucleosomal histone $\mathrm{H} 2 \mathrm{~A}$ induced by diverse apoptogenic stimuli. Cell Death Differ 8(12): 11821196.

80. Briggs SD, Xiao T, Sun ZW, Caldwell JA, Shabanowitz J, Hunt DF, Allis CD, Strahl BD (2002). Gene silencing: trans-histone regulatory pathway in chromatin. Nature 418(6897): 498.

81. Shahbazian MD, Zhang K, Grunstein M (2005). Histone H2B ubiquitylation controls processive methylation but not monomethylation by Dot1 and Set1. Mol Cell 19(2): 271-277.

82. Nakanishi S, Sanderson BW, Delventhal KM, Bradford WD, Staehling-Hampton K, Shilatifard A (2008). A comprehensive library of histone mutants identifies nucleosomal residues required for H3K4 methylation. Nat Struct Mol Biol 15(8): 881-888.

83. Guccione E, Bassi C, Casadio F, Martinato F, Cesaroni M, Schuchlautz H, Luscher B, Amati B (2007). Methylation of histone H3R2 by PRMT6 and H3K4 by an MLL complex are mutually exclusive. Nature 449(7164): 933-937.

84. Kirmizis A, Santos-Rosa H, Penkett CJ, Singer MA, Vermeulen M, Mann M, Bahler J, Green RD, Kouzarides T (2007). Arginine methylation at histone H3R2 controls deposition of H3K4 trimethylation. Nature 449(7164): 928-932.

85. Lee JS, Smith E, Shilatifard A (2010). The language of histone crosstalk. Cell 142(5): 682-685.

86. Wood A, Shukla A, Schneider J, Lee JS, Stanton JD, Dzuiba T, Swanson SK, Florens L, Washburn MP, Wyrick J, Bhaumik SR, Shilatifard A (2007). Ctk complex-mediated regulation of histone methylation by COMPASS. Mol Cell Biol 27(2): 709-720.

87. Xiao T, Shibata $Y$, Rao B, Laribee RN, O'Rourke R, Buck MJ, Greenblatt JF, Krogan NJ, Lieb JD, Strahl BD (2007). The RNA polymerase II kinase Ctk1 regulates positioning of a $5^{\prime}$ histone methylation boundary along genes. Mol Cell Biol 27(2): 721-731.

88. Kouzarides T (2007). Chromatin modifications and their function. Cell 128(4): 693-705.

89. Santos-Rosa H, Schneider R, Bannister AJ, Sherriff J, Bernstein BE, Emre NC, Schreiber SL, Mellor J, Kouzarides T (2002). Active genes are tri-methylated at K4 of histone H3. Nature 419(6905): 407-411.

90. Bernstein BE, Humphrey EL, Erlich RL, Schneider R, Bouman P, Liu JS, Kouzarides T, Schreiber SL (2002). Methylation of histone H3 Lys 4 in coding regions of active genes. Proc Natl Acad Sci U S A 99(13): 8695-8700.

91. Ng HH, Robert F, Young RA, Struhl K (2003). Targeted recruitment of Set1 histone methylase by elongating Pol II provides a localized mark and memory of recent transcriptional activity. Mol Cell 11(3): 709-719. 
92. Nislow C, Ray E, Pillus L (1997). SET1, a yeast member of the trithorax family, functions in transcriptional silencing and diverse cellular processes. Mol Biol Cell 8(12): 2421-2436. PMID: 9398665

93. Singer MS, Kahana A, Wolf AJ, Meisinger LL, Peterson SE, Goggin C, Mahowald M, Gottschling DE (1998). Identification of high-copy disruptors of telomeric silencing in Saccharomyces cerevisiae. Genetics 150(2): 613-632. PMID: 9755194

94. Mikheyeva IV, Grady PJ, Tamburini FB, Lorenz DR, Cam HP (2014). Multifaceted genome control by Set1 Dependent and Independent of H3K4 methylation and the Set1C/COMPASS complex. PLoS Genet 10(10): e1004740.

95. Bryk M, Briggs SD, Strahl BD, Curcio MJ, Allis CD, Winston F (2002). Evidence that Set1, a factor required for methylation of histone $H 3$, regulates rDNA silencing in $\mathrm{S}$. cerevisiae by a Sir2-independent mechanism. Curr Biol 12(2): 165-170.

96. Ng HH, Ciccone DN, Morshead KB, Oettinger MA, Struhl K (2003). Lysine-79 of histone $\mathrm{H} 3$ is hypomethylated at silenced loci in yeast and mammalian cells: a potential mechanism for position-effect variegation. Proc Natl Acad Sci U S A 100(4): 1820-1825.

97. Faucher D, Wellinger RJ (2010). Methylated H3K4, a transcriptionassociated histone modification, is involved in the DNA damage response pathway. PLoS Genet 6(8).

98. Rizzardi LF, Dorn ES, Strahl BD, Cook JG (2012). DNA replication origin function is promoted by $\mathrm{H} 3 \mathrm{~K} 4$ di-methylation in Saccharomyces cerevisiae. Genetics 192(2): 371-384.

99. Shilatifard A (2012). The COMPASS family of histone H3K4 methylases: mechanisms of regulation in development and disease pathogenesis. Annu Rev Biochem 81(65-95.

100. Shilatifard A (2006). Chromatin modifications by methylation and ubiquitination: implications in the regulation of gene expression. Annu Rev Biochem 75(243-269.

101. Roguev A, Schaft D, Shevchenko A, Pijnappel WW, Wilm M, Aasland R, Stewart AF (2001). The Saccharomyces cerevisiae Set1 complex includes an Ash2 homologue and methylates histone 3 lysine 4. EMBO J 20(24): 7137-7148.

102. Krogan NJ, Dover J, Khorrami S, Greenblatt JF, Schneider J, Johnston M, Shilatifard A (2002). COMPASS, a histone H3 (Lysine 4) methyltransferase required for telomeric silencing of gene expression. J Biol Chem 277(13): 10753-10755.

103. Miller T, Krogan NJ, Dover J, Erdjument-Bromage $H$, Tempst $P$, Johnston M, Greenblatt JF, Shilatifard A (2001). COMPASS: a complex of proteins associated with a trithorax-related SET domain protein. Proc Natl Acad Sci U S A 98(23): 12902-12907.

104. Ryu HY, Rhie BH, Ahn SH (2014). Loss of the Set2 histone methyltransferase increases cellular lifespan in yeast cells. Biochem Biophys Res Commun 446(1): 113-118.

105. Malik S, Bhaumik SR (2010). Mixed lineage leukemia: histone H3 lysine 4 methyltransferases from yeast to human. FEBS J 277(8): 18051821.

106. Wang X, Ju L, Fan J, Zhu Y, Liu X, Zhu K, Wu M, Li L (2014). Histone H3K4 methyltransferase MII1 regulates protein glycosylation and tunicamycin-induced apoptosis through transcriptional regulation. Biochim Biophys Acta 1843(11): 2592-2602.

107. Pena PV, Hom RA, Hung T, Lin H, Kuo AJ, Wong RP, Subach OM, Champagne KS, Zhao R, Verkhusha VV, Li G, Gozani O, Kutateladze TG (2008). Histone H3K4me3 binding is required for the DNA repair and apoptotic activities of ING1 tumor suppressor. Journal of molecular biology 380(2): 303-312.
108. Tyagi S, Herr W (2009). E2F1 mediates DNA damage and apoptosis through HCF-1 and the MLL family of histone methyltransferases. EMBO J 28(20): 3185-3195.

109. Hung T, Binda O, Champagne KS, Kuo AJ, Johnson K, Chang HY, Simon MD, Kutateladze TG, Gozani O (2009). ING4 mediates crosstalk between histone $\mathrm{H} 3 \mathrm{~K} 4$ trimethylation and $\mathrm{H} 3$ acetylation to attenuate cellular transformation. Mol Cell 33(2): 248-256.

110. Jones B, Su H, Bhat A, Lei H, Bajko J, Hevi S, Baltus GA, Kadam S, Zhai H, Valdez R, Gonzalo S, Zhang Y, Li E, Chen T (2008). The histone H3K79 methyltransferase Dot1L is essential for mammalian development and heterochromatin structure. PLoS Genet 4(9): e1000190.

111. Shanower GA, Muller M, Blanton JL, Honti V, Gyurkovics H, Schedl P (2005). Characterization of the grappa gene, the Drosophila histone H3 lysine 79 methyltransferase. Genetics 169(1): 173-184.

112. van Leeuwen F, Gafken PR, Gottschling DE (2002). Dot1p modulates silencing in yeast by methylation of the nucleosome core. Cell 109(6): 745-756.

113. Feng $Q$, Wang $H, N g ~ H H$, Erdjument-Bromage $H$, Tempst $P$, Struhl $\mathrm{K}$, Zhang $\mathrm{Y}$ (2002). Methylation of H3-lysine 79 is mediated by a new family of HMTases without a SET domain. Curr Biol 12(12): 1052-1058.

114. $\mathrm{Ng} \mathrm{HH}$, Feng $\mathrm{Q}$, Wang $\mathrm{H}$, Erdjument-Bromage $\mathrm{H}$, Tempst $\mathrm{P}$, Zhang $Y$, Struhl $K$ (2002). Lysine methylation within the globular domain of histone $\mathrm{H} 3$ by Dot1 is important for telomeric silencing and Sir protein association. Genes Dev 16(12): 1518-1527.

115. Lacoste N, Utley RT, Hunter JM, Poirier GG, Cote J (2002). Disruptor of telomeric silencing-1 is a chromatin-specific histone H3 methyltransferase. J Biol Chem 277(34): 30421-30424.

116. Wysocki R, Javaheri A, Allard S, Sha F, Cote J, Kron SJ (2005). Role of Dot1-dependent histone H3 methylation in $\mathrm{G} 1$ and S phase DNA damage checkpoint functions of Rad9. Mol Cell Biol 25(19): 84308443.

117. Huyen $Y$, Zgheib O, Ditullio RA, Jr., Gorgoulis VG, Zacharatos $P$, Petty TJ, Sheston EA, Mellert HS, Stavridi ES, Halazonetis TD (2004). Methylated lysine 79 of histone $\mathrm{H} 3$ targets 53BP1 to DNA doublestrand breaks. Nature 432(7015): 406-411.

118. Tatum D, Li S (2011). Evidence that the histone methyltransferase Dot1 mediates global genomic repair by methylating histone $\mathrm{H} 3$ on lysine 79. J Biol Chem 286(20): 17530-17535.

119. Chaudhuri S, Wyrick JJ, Smerdon MJ (2009). Histone H3 Lys79 methylation is required for efficient nucleotide excision repair in a silenced locus of Saccharomyces cerevisiae. Nucleic Acids Res 37(5): 1690-1700.

120. Okada $Y$, Feng $Q$, Lin $Y$, Jiang $Q$, Li $Y$, Coffield VM, Su L, Xu G, Zhang $Y$ (2005). hDOT1L links histone methylation to leukemogenesis. Cell 121(2): 167-178.

121. Mohan M, Herz HM, Takahashi YH, Lin C, Lai KC, Zhang Y, Washburn MP, Florens L, Shilatifard A (2010). Linking H3K79 trimethylation to Wnt signaling through a novel Dot1-containing complex (DotCom). Genes Dev 24(6): 574-589.

122. Oberdoerffer $P$, Sinclair DA (2007). The role of nuclear architecture in genomic instability and ageing. Nat Rev Mol Cell Biol 8(9): 692-702.

123. Kim S, Villeponteau B, Jazwinski SM (1996). Effect of replicative age on transcriptional silencing near telomeres in Saccharomyces cerevisiae. Biochem Biophys Res Commun 219(2): 370-376.

124. Smeal T, Claus J, Kennedy B, Cole F, Guarente L (1996). Loss of transcriptional silencing causes sterility in old mother cells of $\mathrm{S}$. cerevisiae. Cell 84(4): 633-642. PMID: 8598049. 
125. Kim S, Benguria A, Lai CY, Jazwinski SM (1999). Modulation of lifespan by histone deacetylase genes in Saccharomyces cerevisiae. Mol Biol Cell 10(10): 3125-3136. PMID: 10512855

126. Brachmann CB, Sherman JM, Devine SE, Cameron EE, Pillus L, Boeke JD (1995). The SIR2 gene family, conserved from bacteria to humans, functions in silencing, cell cycle progression, and chromosome stability. Genes Dev 9(23): 2888-2902. PMID: 7498786

127. Bryk M, Banerjee M, Murphy M, Knudsen KE, Garfinkel DJ, Curcio MJ (1997). Transcriptional silencing of Ty1 elements in the RDN1 locus of yeast. Genes Dev 11(2): 255-269. PMID: 9009207

128. Fritze CE, Verschueren K, Strich R, Easton Esposito R (1997). Direct evidence for SIR2 modulation of chromatin structure in yeast rDNA. EMBO J 16(21): 6495-6509.

129. Smith JS, Boeke JD (1997). An unusual form of transcriptional silencing in yeast ribosomal DNA. Genes Dev 11(2): 241-254. PMID: 9009206

130. Smith JS, Brachmann CB, Pillus L, Boeke JD (1998). Distribution of a limited Sir2 protein pool regulates the strength of yeast rDNA silencing and is modulated by Sir4p. Genetics 149(3): 1205-1219. PMID: 9649515

131. Kaeberlein M, McVey M, Guarente L (1999). The SIR2/3/4 complex and SIR2 alone promote longevity in Saccharomyces cerevisiae by two different mechanisms. Genes Dev 13(19): 25702580. PMID: 10521401

132. Lamming DW, Latorre-Esteves M, Medvedik O, Wong SN, Tsang FA, Wang C, Lin SJ, Sinclair DA (2005). HST2 mediates SIR2independent life-span extension by calorie restriction. Science 309(5742): 1861-1864.

133. Gottlieb S, Esposito RE (1989). A new role for a yeast transcriptional silencer gene, SIR2, in regulation of recombination in ribosomal DNA. Cell 56(5): 771-776. PMID: 2647300.

134. Dang W, Steffen KK, Perry R, Dorsey JA, Johnson FB, Shilatifard A, Kaeberlein M, Kennedy BK, Berger SL (2009). Histone H4 lysine 16 acetylation regulates cellular lifespan. Nature 459(7248): 802-807.

135. Feser J, Truong D, Das C, Carson JJ, Kieft J, Harkness T, Tyler JK (2010). Elevated histone expression promotes life span extension. Mol Cell 39(5): 724-735.

136. Li J, Moazed D, Gygi SP (2002). Association of the histone methyltransferase Set2 with RNA polymerase II plays a role in transcription elongation. J Biol Chem 277(51): 49383-49388.

137. Strahl BD, Grant PA, Briggs SD, Sun ZW, Bone JR, Caldwell JA, Mollah S, Cook RG, Shabanowitz J, Hunt DF, Allis CD (2002). Set2 is a nucleosomal histone $\mathrm{H} 3$-selective methyltransferase that mediates transcriptional repression. Mol Cell Biol 22(5): 1298-1306.

138. Ng HH, Xu RM, Zhang Y, Struhl K (2002). Ubiquitination of histone $\mathrm{H} 2 \mathrm{~B}$ by Rad6 is required for efficient Dot1-mediated methylation of histone H3 lysine 79. J Biol Chem 277(38): 34655-34657.

139. Li B, Howe L, Anderson S, Yates JR, 3rd, Workman JL (2003). The Set2 histone methyltransferase functions through the phosphorylated carboxyl-terminal domain of RNA polymerase II. J Biol Chem 278(11): 8897-8903.

140. Schaft D, Roguev A, Kotovic KM, Shevchenko A, Sarov M, Shevchenko A, Neugebauer KM, Stewart AF (2003). The histone 3 lysine 36 methyltransferase, SET2, is involved in transcriptional elongation. Nucleic Acids Res 31(10): 2475-2482.

141. Xiao T, Hall H, Kizer KO, Shibata $Y$, Hall MC, Borchers $\mathrm{CH}$, Strahl BD (2003). Phosphorylation of RNA polymerase II CTD regulates H3 methylation in yeast. Genes Dev 17(5): 654-663.
142. Pu M, Ni Z, Wang M, Wang X, Wood JG, Helfand SL, Yu H, Lee SS (2015). Trimethylation of Lys36 on $\mathrm{H} 3$ restricts gene expression change during aging and impacts life span. Genes Dev 29(7): 718-731.

143. Chen CC, Carson JJ, Feser J, Tamburini B, Zabaronick S, Linger J, Tyler JK (2008). Acetylated lysine 56 on histone H3 drives chromatin assembly after repair and signals for the completion of repair. Cell 134(2): 231-243.

144. Ramey CJ, Howar S, Adkins M, Linger J, Spicer J, Tyler JK (2004). Activation of the DNA damage checkpoint in yeast lacking the histone chaperone anti-silencing function 1. Mol Cell Biol 24(23): 1031310327.

145. Tyler JK, Adams CR, Chen SR, Kobayashi R, Kamakaka RT, Kadonaga JT (1999). The RCAF complex mediates chromatin assembly during DNA replication and repair. Nature 402(6761): 555-560.

146. Schneider J, Bajwa P, Johnson FC, Bhaumik SR, Shilatifard A (2006). Rtt109 is required for proper H3K56 acetylation: a chromatin mark associated with the elongating RNA polymerase II. J Biol Chem 281(49): 37270-37274.

147. Maas NL, Miller KM, DeFazio LG, Toczyski DP (2006). Cell cycle and checkpoint regulation of histone H3 K56 acetylation by Hst3 and Hst4. Mol Cell 23(1): 109-119.

148. Tsuchiya M, Dang N, Kerr EO, Hu D, Steffen KK, Oakes JA, Kennedy BK, Kaeberlein M (2006). Sirtuin-independent effects of nicotinamide on lifespan extension from calorie restriction in yeast. Aging Cell 5(6): 505-514.

149. Spector MS, Osley MA (1993). The HIR4-1 mutation defines a new class of histone regulatory genes in Saccharomyces cerevisiae. Genetics 135(1): 25-34. PMID: 8224824

150. Spector MS, Raff A, DeSilva H, Lee K, Osley MA (1997). Hir1p and Hir2 $p$ function as transcriptional corepressors to regulate histone gene transcription in the Saccharomyces cerevisiae cell cycle. Mol Cell Biol 17(2): 545-552. PMID: 9001207

151. O'Sullivan RJ, Kubicek S, Schreiber SL, Karlseder J (2010). Reduced histone biosynthesis and chromatin changes arising from a damage signal at telomeres. Nat Struct Mol Biol 17(10): 1218-1225.

152. Downs JA, Lowndes NF, Jackson SP (2000). A role for Saccharomyces cerevisiae histone $\mathrm{H} 2 \mathrm{~A}$ in DNA repair. Nature 408(6815): 1001-1004.

153. Keogh MC, Kim JA, Downey M, Fillingham J, Chowdhury D, Harrison JC, Onishi M, Datta N, Galicia S, Emili A, Lieberman J, Shen X, Buratowski S, Haber JE, Durocher D, Greenblatt JF, Krogan NJ (2006). A phosphatase complex that dephosphorylates gammaH2AX regulates DNA damage checkpoint recovery. Nature 439(7075): 497-501.

154. Liang G, Klose RJ, Gardner KE, Zhang Y (2007). Yeast Jhd2p is a histone H3 Lys4 trimethyl demethylase. Nat Struct Mol Biol 14(3): 243-245.

155. Greer EL, Maures TJ, Hauswirth AG, Green EM, Leeman DS, Maro GS, Han S, Banko MR, Gozani O, Brunet A (2010). Members of the H3K4 trimethylation complex regulate lifespan in a germlinedependent manner in C. elegans. Nature 466(7304): 383-387.

156. Tu S, Bulloch EM, Yang L, Ren C, Huang WC, Hsu PH, Chen $\mathrm{CH}$, Liao CL, Yu HM, Lo WS, Freitas MA, Tsai MD (2007). Identification of histone demethylases in Saccharomyces cerevisiae. J Biol Chem 282(19): 14262-14271.

157. Lee JH, Kang BH, Jang H, Kim TW, Choi J, Kwak S, Han J, Cho EJ, Youn HD (2015). AKT phosphorylates H3-threonine 45 to facilitate termination of gene transcription in response to DNA damage. Nucleic Acids Res 43(9): 4505-4516. 
158. Hiraga S, Botsios S, Donaldson AD (2008). Histone H3 lysine 56 acetylation by Rtt109 is crucial for chromosome positioning. J Cell Biol 183(4): 641-651.

159. Kozak ML, Chavez A, Dang W, Berger SL, Ashok A, Guo X, Johnson FB (2010). Inactivation of the Sas2 histone acetyltransferase delays senescence driven by telomere dysfunction. EMBO J 29(1): 158-170.

160. Vaquero A, Sternglanz R, Reinberg D (2007). NAD+-dependent deacetylation of $\mathrm{H} 4$ lysine 16 by class III HDACs. Oncogene 26(37): 5505-5520.

161. Eisenberg T, Knauer H, Schauer A, Buttner S, Ruckenstuhl C, Carmona-Gutierrez D, Ring J, Schroeder S, Magnes C, Antonacci L, Fussi H, Deszcz L, Hartl R, Schraml E, Criollo A, Megalou E, Weiskopf D, Laun P, Heeren G, Breitenbach M, Grubeck-Loebenstein B, Herker E, Fahrenkrog B, Frohlich KU, Sinner F, Tavernarakis N, Minois N, Kroemer G, Madeo F (2009). Induction of autophagy by spermidine promotes longevity. Nat Cell Biol 11(11): 1305-1314.

162. Madeo F, Eisenberg T, Buttner S, Ruckenstuhl C, Kroemer G (2010). Spermidine: a novel autophagy inducer and longevity elixir. Autophagy 6(1): 160-162.

163. Scalabrino G, Ferioli ME (1984). Polyamines in mammalian ageing: an oncological problem, too? A review. Mech Ageing Dev 26(2-3): 149-164.

164. Eisenberg T, Schroeder S, Andryushkova A, Pendl T, Kuttner V, Bhukel A, Marino G, Pietrocola F, Harger A, Zimmermann A, Moustafa $T$, Sprenger A, Jany E, Buttner S, Carmona-Gutierrez D, Ruckenstuhl C, Ring J, Reichelt W, Schimmel K, Leeb T, Moser C, Schatz S, Kamolz LP, Magnes C, Sinner F, Sedej S, Frohlich KU, Juhasz G, Pieber TR, Dengjel J, et al. (2014). Nucleocytosolic depletion of the energy metabolite acetyl-coenzyme a stimulates autophagy and prolongs lifespan. Cell metabolism 19(3): 431-444.

165. Schroeder S, Pendl T, Zimmermann A, Eisenberg T, CarmonaGutierrez D, Ruckenstuhl C, Marino G, Pietrocola F, Harger A, Magnes C, Sinner F, Pieber TR, Dengjel J, Sigrist SJ, Kroemer G, Madeo F (2014) Acetyl-coenzyme A: a metabolic master regulator of autophagy and longevity. Autophagy 10(7): 1335-1337.
166. Fullgrabe J, Lynch-Day MA, Heldring N, Li W, Struijk RB, Ma Q, Hermanson O, Rosenfeld MG, Klionsky DJ, Joseph B (2013). The histone $\mathrm{H} 4$ lysine 16 acetyltransferase hMOF regulates the outcome of autophagy. Nature 500(7463): 468-471.

167. Chen $H$, Fan M, Pfeffer LM, Laribee RN (2012). The histone H3 lysine 56 acetylation pathway is regulated by target of rapamycin (TOR) signaling and functions directly in ribosomal RNA biogenesis. Nucleic Acids Res 40(14): 6534-6546.

168. Taniue K, Oda T, Hayashi T, Okuno M, Akiyama T (2011). A member of the ETS family, EHF, and the ATPase RUVBL1 inhibit p53mediated apoptosis. EMBO Rep 12(7): 682-689.

169. Liu W, Deng L, Song $Y$, Redell M (2014). DOT1L inhibition sensitizes MLL-rearranged AML to chemotherapy. PLoS One 9(5): e98270.

170. Prokhorova EA, Zamaraev AV, Kopeina GS, Zhivotovsky B, Lavrik IN (2015). Role of the nucleus in apoptosis: signaling and execution. Cell Mol Life Sci 72(23): 4593-4612.

171. Chandrasekharan MB, Huang F, Sun ZW (2010). Histone H2B ubiquitination and beyond: Regulation of nucleosome stability, chromatin dynamics and the trans-histone H3 methylation. Epigenetics 5(6): 460-468.

172. Wood A, Schneider J, Shilatifard A (2005). Cross-talking histones: implications for the regulation of gene expression and DNA repair. Biochem Cell Biol 83(4): 460-467.

173. Nur EKA, Gross SR, Pan Z, Balklava Z, Ma J, Liu LF (2004). Nuclear translocation of cytochrome c during apoptosis. J Biol Chem 279(24): 24911-24914.

174. Bose P, Thakur S, Thalappilly S, Ahn BY, Satpathy S, Feng X, Suzuki K, Kim SW, Riabowol K (2013). ING1 induces apoptosis through direct effects at the mitochondria. Cell death \& disease 4:e788. 